\title{
molecules
}

ISSN 1420-3049

http://www.mdpi.org

Full Paper

\section{Methyl Jasmonate and Salicylic Acid Induced Oxidative Stress and Accumulation of Phenolics in Panax ginseng Bioreactor Root Suspension Cultures}

\author{
Mohammad Babar Ali ${ }^{1}$, Eun-Joo Hahn ${ }^{2}$ and Kee-Yoeup Paek ${ }^{2, *}$ \\ ${ }^{1}$ Metabolic Regulation Laboratory, Food Biotechnology Division, National Food Research Institute, \\ Kannondai, Tsukuba, Ibaraki-305-8642, Japan; E-mail: alimbjp@affrc.go.jp or \\ alimb@rediffmail.com; Phone: (+81)-29-838-8050; Fax: (+81)-29-838-8122 \\ 2 Research Center for the Development of Advanced Horticultural Technology, Chungbuk National \\ University, Cheong-ju, 361-763, Republic of Korea; Phone: (+82)-43-261-3245; Fax: (+82)-43-272- \\ 5369; E-mails: ejhahn@cbnu.ac.kr; paekky@cbnu.ac.kr
}

* Author to whom correspondence should be addressed; E-mail: paekky@cbnu.ac.kr

Received: 24 January 2007; in revised form: 13 March 2007 / Accepted: 18 March 2007 / Published: 23 March 2007

\begin{abstract}
To investigate the enzyme variations responsible for the synthesis of phenolics, 40 day-old adventitious roots of Panax ginseng were treated with $200 \mu \mathrm{M}$ methyl jasmonate (MJ) or salicylic acid (SA) in a $5 \mathrm{~L}$ bioreactor suspension culture (working volume $4 \mathrm{~L}$ ). Both treatments caused an increase in the carbonyl and hydrogen peroxide $\left(\mathrm{H}_{2} \mathrm{O}_{2}\right)$ contents, although the levels were lower in SA treated roots. Total phenolic, flavonoid, ascorbic acid, non-protein thiol (NPSH) and cysteine contents and 1,1-diphenyl-2-picrylhydrazyl (DPPH) radical reducing activity were increased by MJ and SA. Fresh weight (FW) and dry weight (DW) decreased significantly after 9 days of exposure to SA and MJ. The highest total phenolics (62\%), DPPH activity (40\%), flavonoids (88\%), ascorbic acid (55\%), NPSH (33\%), and cysteine (62\%) contents compared to control were obtained after 9 days in SA treated roots. The activities of glucose 6-phosphate dehydrogenase, phenylalanine ammonia lyase, substrate specific peroxidases (caffeic acid peroxidase, quercetin peroxidase and ferulic acid peroxidase) were higher in MJ treated roots than the SA treated ones. Increased shikimate dehydrogenase, chlorogenic acid peroxidase and $\beta$-glucosidase activities and proline content were observed in SA treated roots than in MJ ones. Cinnamyl alcohol
\end{abstract}


dehydrogenase activity remained unaffected by both MJ and SA. These results strongly indicate that $\mathrm{MJ}$ and SA induce the accumulation of phenolic compounds in ginseng root by altering the phenolic synthesis enzymes.

Keywords: Antioxidant capacity; cysteine; phenylpropanoid pathway enzymes; Panax ginseng; phenolics.

Abbreviations: CA, caffeic acid peroxidase; CGA, chlorogenic acid peroxidase; CAD, cinnamyl alcohol dehydrogenase; CBN-1, Chungbuk National University line-1; DPPH, 1,1-diphenyl-2-picrylhydrazyl; FA, ferulic acid peroxidase, G6PDH, glucose 6 phosphate dehydrogenase; $\beta$-GS, $\beta$-glucosidase; MJ, methyl jasmonate; NPSH, non-protein thiol; $\mathrm{PAL}$, phenylalanine ammonia lyase; $\mathrm{QP}$, quercetin peroxidase; SA, salicylic acid; SKDH, shikimate dehydrogenase.

\section{Introduction}

Phenolic compounds are naturally occurring substances in plants, many of which are thought to play physiological roles such as antibacterial, antiviral, anticancer agents and scavengers of most types of oxidizing molecules [1]. Under biotic and abiotic stresses such as pathogen attack, physical wounding, and UV-light exposure, plants can induce a defense response and increase secondary metabolite levels [2]. In relation to this, increased activity of phenylalanine ammonia lyase (PAL) and other related enzymes such as peroxidase has been reported in plants subjected to various stresses [3]. They are synthesized primarily through the pentose phosphate pathway (PPP) and shikimate pathways [4]. G6PDH plays a significant role in carbon metabolism of plants since it catalyzes the first reaction in the oxidative pentose phosphate pathway. The main function of G6PDH is to provide the precursor erythrose-4-phosphate for the shikimate pathway, which converts these sugar phosphates to aromatic amino acids like phenylalanine, which becomes in turn the precursor for the phenylpropanoid pathway that synthesizes phenolics $[5,6]$. The phenylpropanoid pathway is the main metabolic route for the synthesis of natural secondary metabolites such as phenolics, flavonoids, lignin etc. PAL is a crucial enzyme in the phenylpropanoid pathway, catalyzing the formation of trans-cinnamic acid via the Ldeamination of phenylalanine. Cinnamyl alcohol dehydrogenases catalyse the reversible conversion of p-hydroxycinnamaldehydes to their corresponding alcohols, leading to the biosynthesis of lignin in plants [7]. Peroxidases are ionically bound to the cell walls and are involved in the polymerization of phenylpropanoid lignin precursors [8]. Oxidation of peroxidases makes the cell wall more mechanically rigid by cross-linking matrix polysaccharide and glycoprotein molecules, thus modifying the mechanical properties of the cell wall. In general, cross linking of matrix polysaccharides in cell walls are also likely to inhibit cell wall degrading enzymes of the pathogen.

Panax ginseng (C.A. Meyer) is recognized as a high value medicinal plant and its usefulness as a general tonic has been proven. The main ingredients of ginseng are more than 27 saponin triterpenoid glycosides called ginsenosides [9, 10]. Ginseng, however, is a slow growing plant and its root becomes useful only when the plant reaches 4-6 years of age. With increasing demand for ginseng worldwide, 
alternative methods are necessary for the growth of plant material. Plant cell culture is an important plant biotechnology tool and one of its potential applications is for the production of valuable plant secondary metabolites. Exogenous application of methyl jasmonate and/or salicylic acid could induce the expression of many defense genes in different plants $[11,12]$. Our previous studies have shown that exogenous application of MJ and SA increases ginsenoside content in $P$. ginseng [13]. Phenolic compounds are ubiquitous in all plant organs and are, therefore, an integral part of the human diet. Interest in food phenolics has recently increased greatly because of the antioxidant and free radical scavenging abilities, associated with some phenolic compounds and their potential effects on human health [14]. Limited attention has been paid, however, to the effects on phenolic compounds and related enzymes on the response to MJ and SA. Therefore, the present work was aimed towards studying the effect of MJ and SA on the induction of phenolic compounds, the related biosynthetic enzymes and antioxidant levels to illuminate the possible role of MJ and SA in the elicitor mediated induction of the phenolic compounds in root suspension culture of $P$. ginseng.

\section{Results}

The root growth was measured as fresh weight (FW) and dry weight (DW) at 0, 3, 5, 7 and 9 days after treatment. The results are shown in Table 1.

Table 1. The effect of methyl jasmonate (MJ) or salicylic acid (SA) on ginseng root growth after $0,3,5,7$ and 9 days of bioreactor culture.

\begin{tabular}{|c|c|c|c|c|}
\multicolumn{4}{|c}{$\mathrm{MJ}(200 \mu \mathrm{M})$} \\
\hline Duration & $\mathrm{FW}\left(\mathrm{g} \mathrm{L}^{-1}\right)$ & $\mathrm{DW}\left(\mathrm{g} \mathrm{L}^{-1}\right)$ & $\mathrm{FW}\left(\mathrm{g} \mathrm{L}^{-1}\right)$ & $\mathrm{DW}\left(\mathrm{g} \mathrm{L}^{-1}\right)$ \\
\hline 0 day & $20.21^{\mathrm{a}} \pm 2.11$ & $4.34^{\mathrm{a}} \pm 0.06$ & $20.21^{\mathrm{a}} \pm 0.16$ & $4.34^{\mathrm{a}} \pm 0.48$ \\
3 days (Control) & $20.23^{\mathrm{a}} \pm 2.15$ & $4.35^{\mathrm{a}} \pm 0.12$ & $20.22^{\mathrm{a}} \pm 0.14$ & $4.37^{\mathrm{a}} \pm 0.35$ \\
3 days & $20.35^{\mathrm{a}} \pm 2.23$ & $4.54^{\mathrm{a}} \pm 0.15$ & $20.25^{\mathrm{a}} \pm 0.15$ & $4.41^{\mathrm{a}} \pm 0.52$ \\
5 days (Control) & $20.12^{\mathrm{a}} \pm 1.68$ & $4.35^{\mathrm{a}} \pm 0.09$ & $20.12^{\mathrm{a}} \pm 0.18$ & $4.35^{\mathrm{a}} \pm 0.47$ \\
5 days & $19.82^{\mathrm{a}} \pm 1.86$ & $4.45^{\mathrm{a}} \pm 0.15$ & $19.82^{\mathrm{a}} \pm 0.23$ & $4.39^{\mathrm{a}} \pm 0.44$ \\
7 days (Control) & $19.98^{\mathrm{a}} \pm 1.44$ & $4.31^{\mathrm{a}} \pm 0.16$ & $19.98^{\mathrm{a}} \pm 0.13$ & $4.31^{\mathrm{a}} \pm 0.24$ \\
7 days & $19.78^{\mathrm{a}} \pm 1.64$ & $4.15^{\mathrm{a}} \pm 0.08$ & $19.68^{\mathrm{a}} \pm 0.25$ & $3.88^{\mathrm{a}} \pm 0.31$ \\
9 days (Control) & $19.88^{\mathrm{a}} \pm 1.33$ & $4.22^{\mathrm{a}} \pm 0.22$ & $19.88^{\mathrm{a}} \pm 0.32$ & $4.22^{\mathrm{a}} \pm 0.28$ \\
9 days & $19.61^{\mathrm{a}} \pm 1.53$ & $4.12^{\mathrm{a}} \pm 0.17$ & $17.13^{\mathrm{a}} \pm 0.21$ & $3.23^{\mathrm{b}} \pm 0.22$ \\
\hline
\end{tabular}

Both treatments led to decreased biomass after the $7^{\text {th }}$ day, while root DW after SA treatment decreased $25 \%$ and that after MJ treatment decreased $10 \%$ by day 9 , compared to control. On the other hand, DW was almost the same on days 3 and 5, compared to the control. MJ and SA significantly elevated the amount of $\mathrm{H}_{2} \mathrm{O}_{2}$ (Figure 1A) and carbonyl content (Figure 1B), compared to the control. Figures 2A-F show the total phenols, flavonoids, ascorbic acid, cysteine and NPSH contents and DPPH reducing activity after MJ and SA treatment. The maximum yields of phenols, DPPH activity, flavonoids, ascorbic acid, cysteine and NPSH content were $0.78 \mathrm{mg} \mathrm{g}^{-1} \mathrm{FW}, 58.27 \%, 4.88 \mathrm{mg} \mathrm{g}^{-1} \mathrm{FW}$, 
$3.33 \mathrm{mg} \mathrm{g}^{-1} \mathrm{FW}, 116.3 \mu \mathrm{mol} \mathrm{g}^{-1} \mathrm{FW}$ and $10.4 \mu \mathrm{mol} \mathrm{g}^{-1} \mathrm{FW}$, respectively, after 9 days in SA treated roots.

Figure 1. Effects of methyl jasmonate and salicylic acid on $\mathrm{H}_{2} \mathrm{O}_{2}$ content (A) and carbonyl content (B) in suspension cultures of $P$. ginseng roots. Each value is the mean \pm S.E. of three independent experiments. Different letters in different bars differ significantly from the control according to DMRT test, ${ }^{a} P<=0.01,{ }^{b} P<=0.05$. Black bars indicate control values, whereas the white bar indicates 45 day-old roots marked as day zero (0).
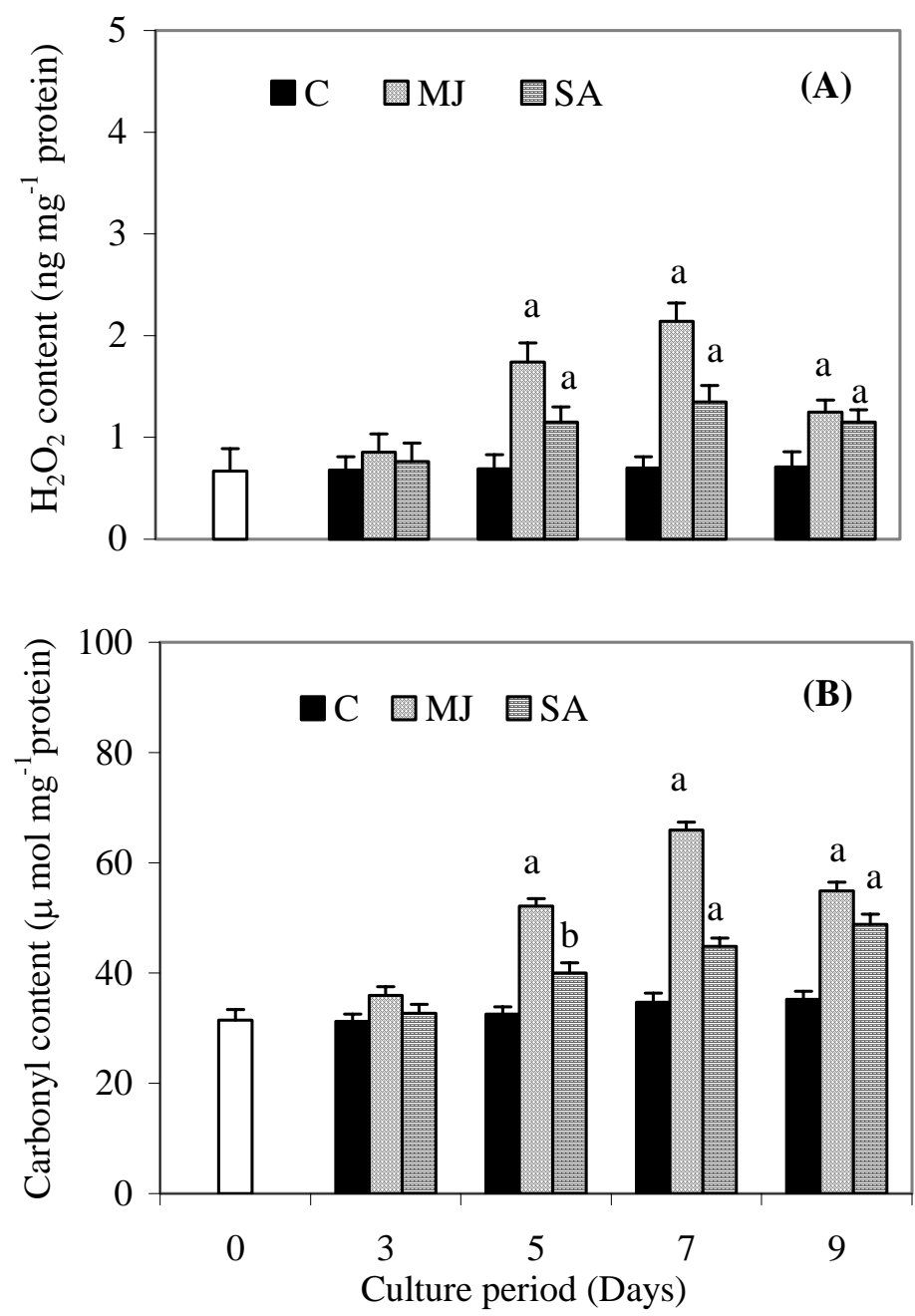

The activities of G6PDH, SKDH, PAL and CAD are shown in Figures 3A-D. MJ and SA treatment resulted in significantly elevated G6PDH activity on all the days, compared to the controls, but MJ caused a $10 \%$ increase in G6PDH activity (Figure 3A) as compared with the SA treatment, while MJ and SA increased G6PDH activity about 35\% and 30\%, compared to control after 9 days. MJ caused a $31 \%$ increase in SKDH activity after 9 days (Figure 3B), while SA caused a 56.6\% and $47 \%$ increase in SKDH activity, as compared to the controls, after 7 and 9 days, respectively. The PAL activity was elevated by MJ and SA treatment after 5, 7 and 9 days (Figure 3C) relative to the control. However, a higher value was obtained in MJ treated roots than in SA ones. MJ and SA both resulted in an increase 
in CAD activity compared to the controls after 3 and 5 days of exposure, but no significant difference in CAD activity was found after 7 and 9 days, compared to the control (Figure 3D).

Figure 2. Effects of methyl jasmonate and salicylic acid on total phenols (A), DPPH activity (B), flavonoids (C), ascorbic acid (D), cysteine content (E) and NPSH content (F) in suspension cultures of $P$. ginseng roots. Each value is the mean \pm S.E. of three independent experiments. Different letters in different bars differ significantly from the control according to DMRT test, ${ }^{a} P<=0.01,{ }^{b} P<=0.05$. Black bars indicate control values, whereas the white bar indicates 45 day-old roots marked as day zero (0).
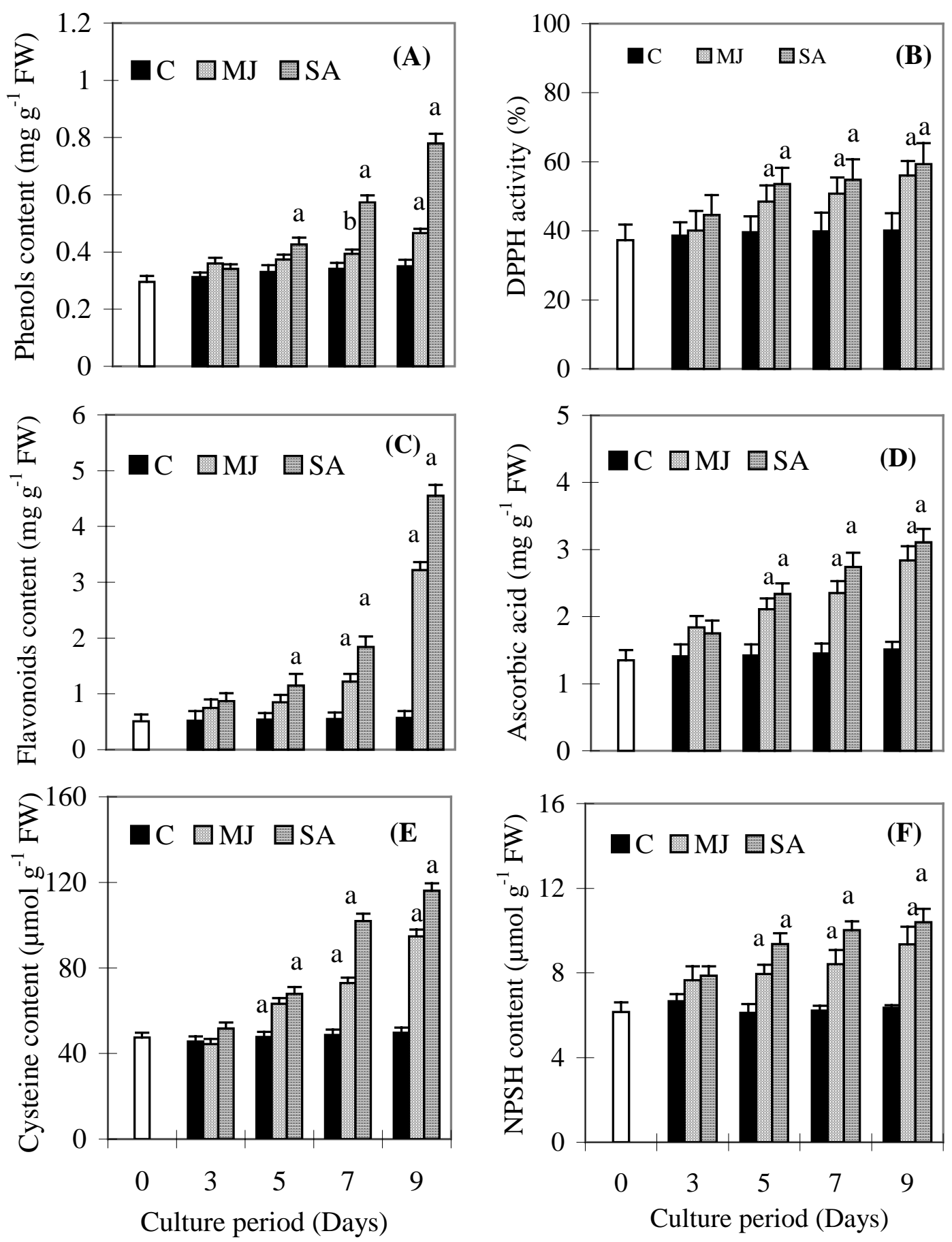
Figure 3. Effects of methyl jasmonate and salicylic acid on the activity of glucose 6 phosphate dehydrogenase (A), shikimate dehydrogenase (B), phenylalanine ammonia lyase (C) and cinnamyl alcohol dehydrogenase (D) in suspension cultures of $P$. ginseng roots. Each value is the mean \pm S.E. of three independent experiments. Different letters in different bars differ significantly from the control according to DMRT test, ${ }^{a} P<=0.01$, ${ }^{b} P<=0.05$. Black bars indicate control values, whereas the white bar indicates 45 dayold roots marked as day zero (0).
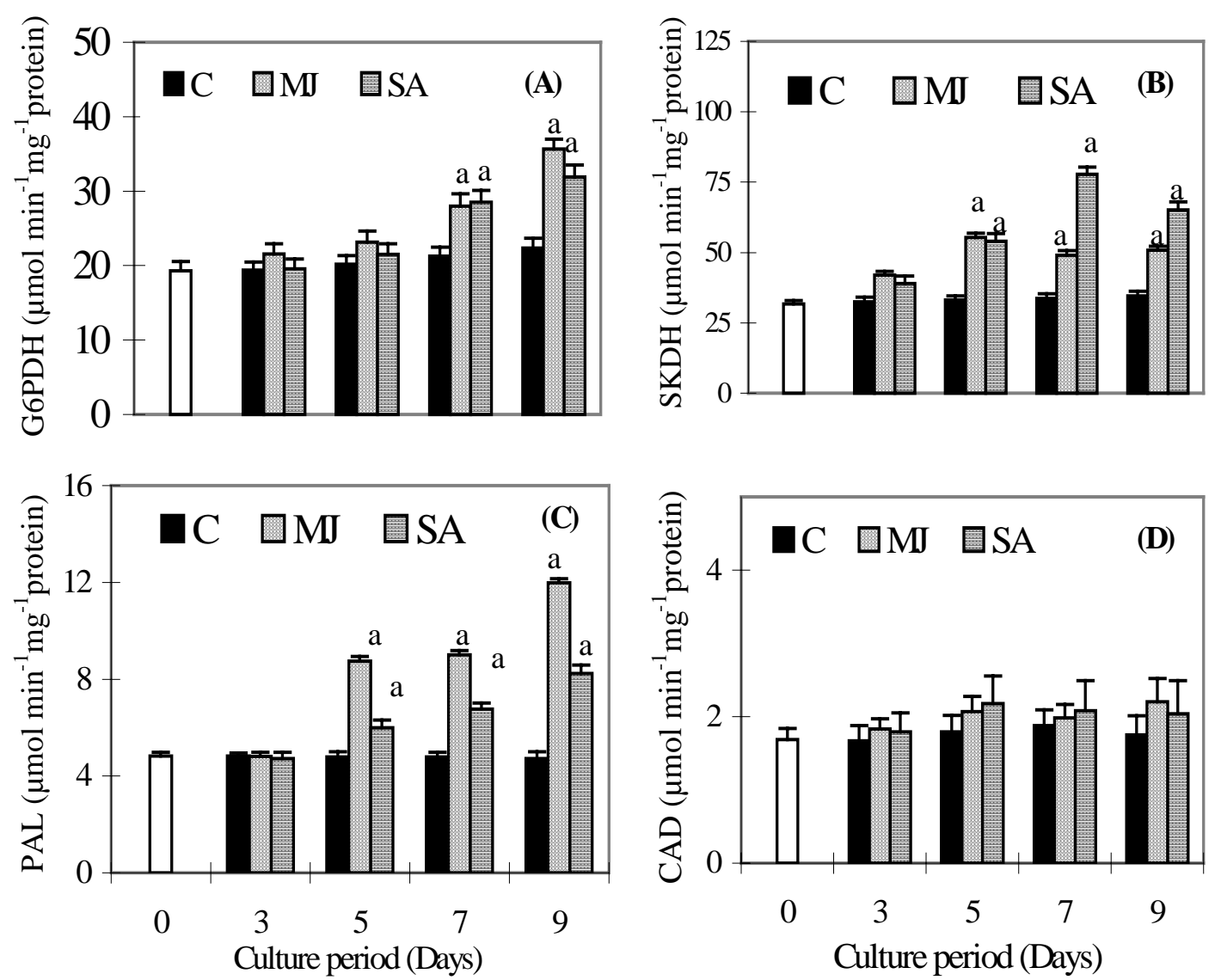

The substrate specific peroxidase activities of CGA, CA, QP and FA are given in Figures 4A-D. CGA activity increased significantly in the SA treated roots on day 3 and then decreased, but it still maintained higher values than the control. It stayed same on all days in MJ treated roots, except on day 5, when it increased significantly compared to the control (Figure 4A). CA activity did not increase in SA treated roots on any day compared to the control (Figure 4B), while MJ treated roots showed higher values compared to the control throughout the culture period. MJ and SA induced QP activities in roots that were higher than the control throughout the culture period (Figure 4C). Levels of FA activity were higher in MJ treated roots than SA ones during the culture period (Figure 4D). A gradual increase was observed in proline content (Figure 5A) and $\beta$-GS activity (Figure 5B) in both treatments throughout the culture period. However, levels of proline content and $\beta$-GS activity were higher in SA treated roots than $\mathrm{MJ}$ ones. 
Figure 4. Effects of methyl jasmonate and salicylic acid on the activity of chlorogenic acid (A), caffeic acid (B), quercetin (C) and ferulic acid (D) dependent peroxidase activities in suspension cultures of $P$. ginseng roots. Each value is the mean \pm S.E. of three independent experiments. Different letters in different bars differ significantly from the control according to DMRT test, ${ }^{a} P<=0.01,{ }^{b} P<=0.05$. Black bars indicate control values, whereas the white bar indicates 45 day-old roots marked as day zero (0).
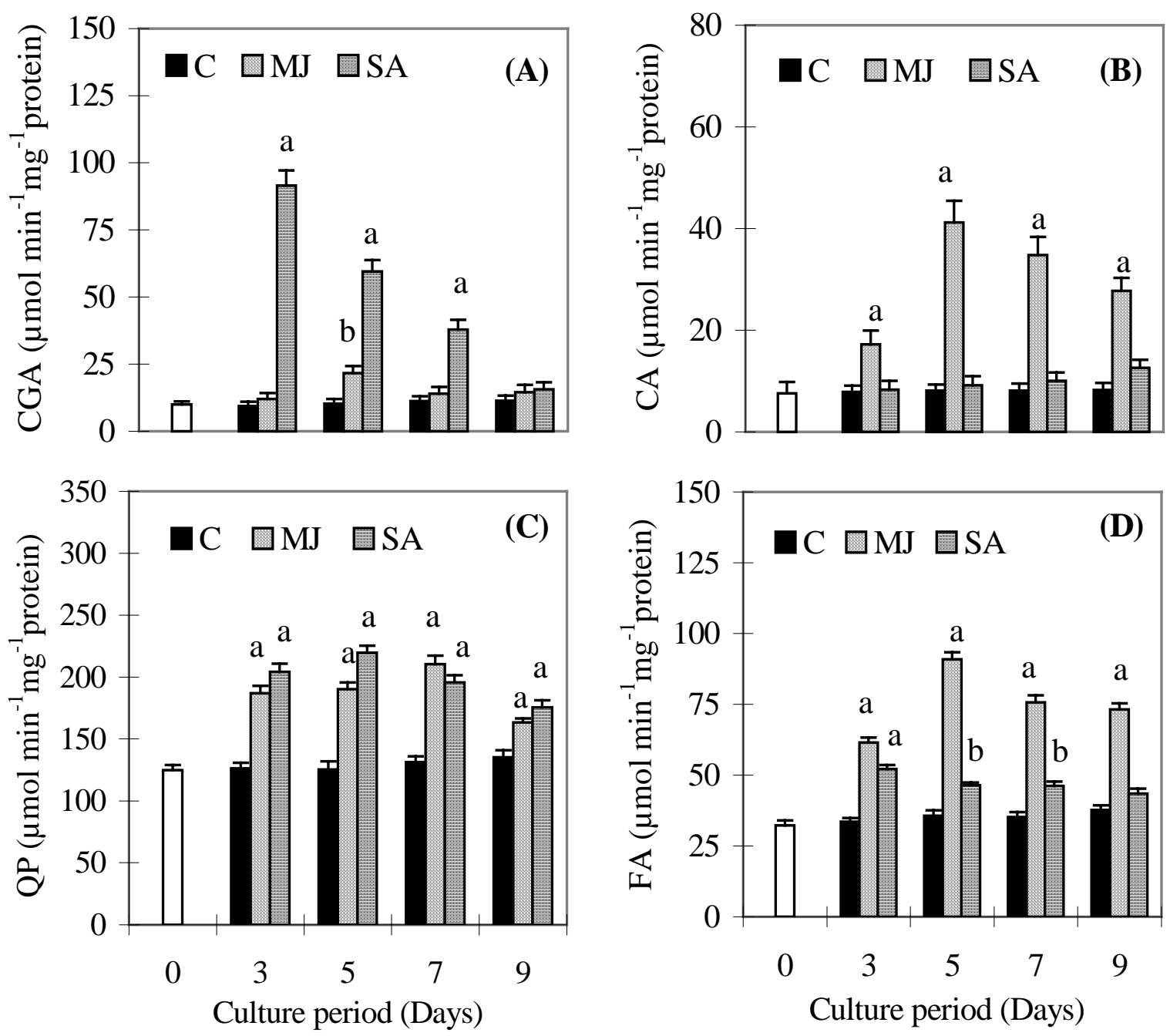

\section{Discussion}

Plants develop a variety of metabolic defense responses against biotic and abiotic stresses such as pathogen attack, physical wounding, including MJ and SA exposure [15, 16]. Defense responses to stress induce the production of several secondary metabolites such as phenolics, flavonoids and other low molecular weight substances [2]. In the present study, there was a significant increase in total phenolics, flavonoids, ascorbic acid, NPSH and cysteine contents and DPPH activity in response to MJ or SA treatment. Flavonoids as one of the most diverse and widespread group of natural compounds, are likely to be the most important natural phenolics with free radical scavenging capacity [17]. A significant increase in the content of total phenolics and flavonoids and DPPH activity at 5, 7 and 9 days of treatment was recorded, but SA treated plants showed greater increases of these parameters than MJ ones. The parallel increases of phenolics and flavonoids levels and DPPH activity indicated 
that the increased free radical scavenging activity might be due to the increased phenolic compound levels induced by MJ and SA treatments. Our results are in accordance with a previous report, which has shown that higher phenolic compound levels increase the antioxidant activity [2] and also showed a linear correlation between phenolics contents and antioxidant activity [18]. Such an induced effect is a possible indication of oxidative stress mediated enhancement, as evidenced by the accumulation of $\mathrm{H}_{2} \mathrm{O}_{2}$ and carbonyl content up to 7 days (Figures $1 \mathrm{~A}$ and $\mathrm{B}$ ).

Figure 5. Effects of methyl jasmonate and salicylic acid on proline content (A) and glucosidase activity (B) in suspension cultures of $P$. ginseng roots. Different letters in different bars differ significantly from the control according to DMRT test, ${ }^{a} P<=0.01$, ${ }^{b} P<=0.05$. Black bars indicate control values, whereas the white bar indicates 45 dayold roots marked as day zero (0).

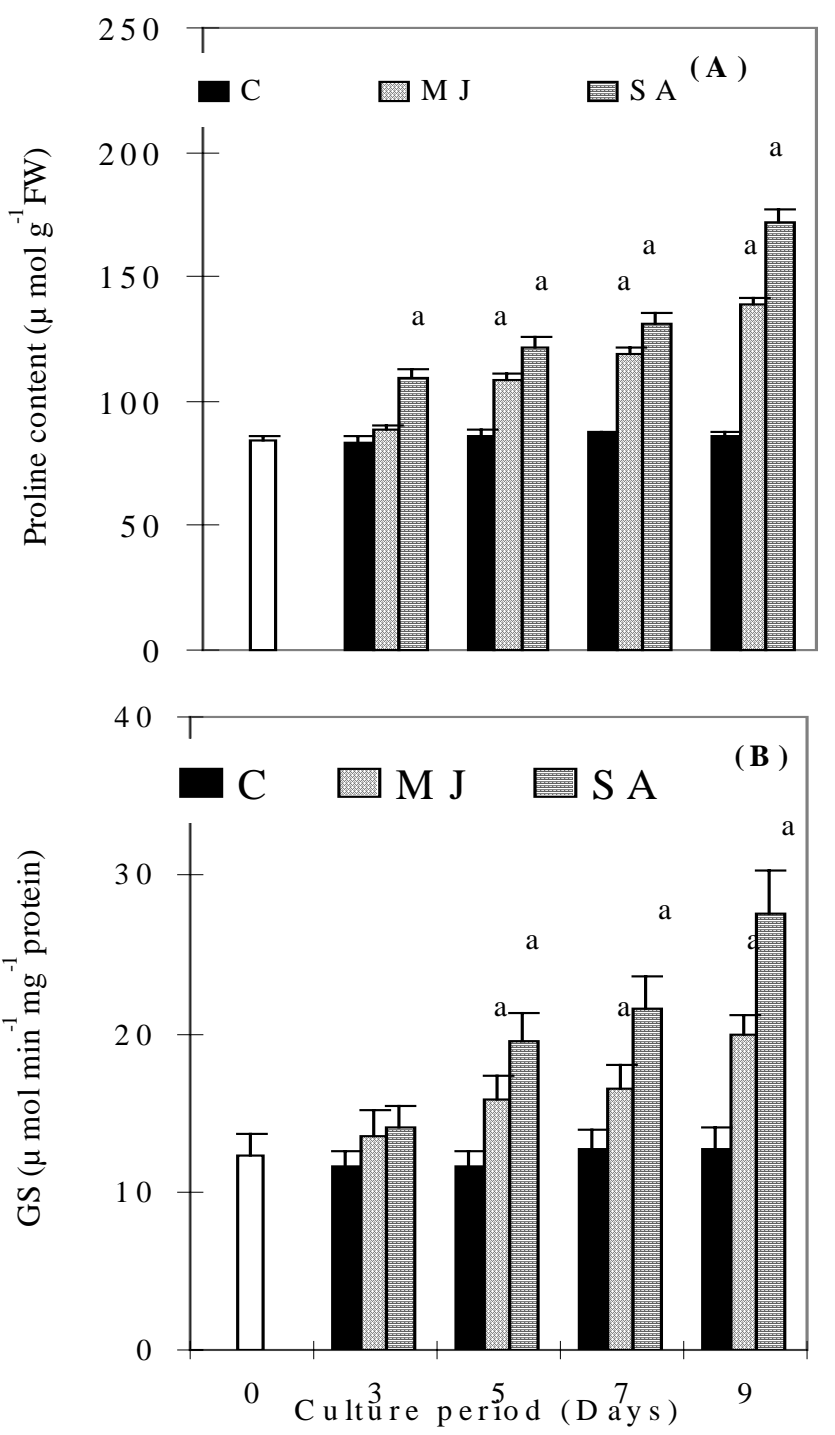

Interestingly, root cultures treated with $\mathrm{MJ}$ and SA accumulated less $\mathrm{H}_{2} \mathrm{O}_{2}$ and carbonyl content at 9 days compared to 7 days. This suggests that induced accumulation of phenolic componds reduced the production of $\mathrm{H}_{2} \mathrm{O}_{2}$ and carbonyl content of $P$. ginseng. Low molecular weight antioxidants (cysteine, NPSH, ascorbic acid, etc.) may also play an important role in inducing tolerance to oxidative stress conditions in plants $[19,20]$. In the present study, induced levels of cysteine, NPSH and ascorbic 
acid were observed in MJ and SA-treated plants. Induced contents of these compounds indicate that the plant has the ability to defend itself from oxidative stress conditions. The coordinated increase of cysteine, NPSH and ascorbic acid corroborate our findings that the function of GSH is linked to that of ascorbic acid and electron flow from NADPH [19]. Proline has multiple functions, such as osmotic pressure regulation, protection of membrane integrity, stabilization of enzymes/proteins, maintaining appropriate $\mathrm{NADP}^{+} / \mathrm{NADPH}$ ratios and scavenger of free radicals [21]. Accumulation of proline under stress conditions such as high salinity, high photosynthetic photon flux, including jasmonic acid presence in plants, has been correlated with stress tolerance [22, 23, 2]. We observed a substantial increase in proline levels with both treatments, which might be attributed to the strategies adapted by plants to cope up with stress conditions. The $\beta$-GSs are a heterogeneous group of enzymes which play important roles in growth, development, detoxification, and defense. They prevent the entry, growth and spread of phytophathogens [24, 25]. Our findings suggest that increase of $\beta$-GS activity in roots of $P$. ginseng under MJ and SA treatment not only increases defense, but also increases the phenolic compound levels. Taken together, it is therefore believed that phenolics and other antioxidants compounds can reduce the harmful effects of stress conditions and thus prevent the development of many types of physiological damage.

MJ and SAs are considered to be plant signaling molecules that play a key role in plant growth, development and defense responses. These signal molecules are involved in some signal transduction systems, which induce particular enzymes of the secondary metabolic pathway to form defense compounds such as phenolics [26, 11]. Exogenous application of MJ and SA may also induce the expression of many defense genes in plants [11]. Thulke and Conrath [27] observed induction of PAL and 4-coumarate:CoA ligase genes in parsley after SA elicitation. The enzymes responsible for the synthesis of phenolics are G6PDH, SKDH, PAL and CAD. Both G6PDH and SKDH enzymes initiate the synthesis of phenolics by synthesizing the appropriate precursors [5,6]. Therefore, the increase of both G6PDH and SKDH activities activates the synthesis of phenolics in MJ and SA treated roots. However, the enhanced activities of both enzymes were different under both elicitors. This may be due to the ROS mediated response, because ROS could stimulate the production of SA and MJ in the roots endogenously and MJ and SA signaling pathways contribute in different ways to the plant [28]. The crucial step for the synthesis of the phenolics in plants is the deamination of L-phenylalanine, producing trans-cinnamic acid [3]. This reaction is catalysed by the PAL enzyme, which is commonly considered the principal enzyme in the biosynthesis of phenolic compounds. A positive correlation (data not shown) between the application of elicitors (MJ and SA) and the increase in PAL activity was found, which in turn led to the accumulation of total phenolics. Furthermore, MJ-treated roots induced more PAL activity than SA ones, however, phenolics content increased more in SA treated roots than MJ ones. These results appear to suggest that MJ and SA act as signaling molecules that cause specific changes in gene expression levels that activate PAL activity and phenolic synthesis differentially [29]. The induced PAL activity not only induces accumulation of phenolics, but also plays an important role in plant defense. Our results agree with several studies that had reported an activation of phenolics accumulation and defense responses in roots of $P$. ginseng [11]. The higher CAD activity in the roots may be closely associated with the higher level of lignin synthesis. However, in our results, CAD activity did not increase significantly, indicating that phenolics were not polymerized to lignin and remained free to act against $\mathrm{H}_{2} \mathrm{O}_{2}$. 
Peroxidase enzyme participates in the construction, rigidification and eventual lignification of cell walls, which protects plant tissues from damage [30, 31]. In our study, SA induced CGA and QP dependent POD activities, while MJ induced FA and CA dependent POD activities significantly compared to respective control. However, most of the POD activities decreased after 9 days but maintained higher values compared to controls indicating that low peroxidase activities could result in low lignification rates in roots of $P$. ginseng and it was also evident by the low activity of CAD after 9 days. This would leave more phenolics available for stress-related antioxidant defense responses. Since the available phenolics were not being used for lignin biosynthesis, this could be the reason for higher phenolics accumulation in SA treated roots, resulting in the increase in the DPPH activity. The induced activities of substrate specific peroxidase under MJ and SA indicate that roots have the ability to remove $\mathrm{H}_{2} \mathrm{O}_{2}$ without any accumulation of oxidised phenolic products.

\section{Conclusions}

This work provides evidence of the role of phenolic compounds, cysteine, NPSH, ascorbic acid, proline content and associated enzymes (phenylpropanoid pathway enzymes and peroxidases) in reducing $M J$ and SA induced stress in roots of $P$. ginseng by scavenging $\mathrm{H}_{2} \mathrm{O}_{2}$ and reducing protein oxidation. The study shows that MJ and SA elicited $P$. ginseng roots have increased antioxidative potential, which protects plants from damage and is probably useful for human health.

\section{Experimental}

\section{Stock root cultures}

Stock roots of $P$. ginseng were maintained in Murashighe and Skoog medium (MS, [32]] supplemented with indolebutyric acid (IBA, $\left.5.0 \mathrm{mg} \mathrm{L}^{-1}\right)$, kinetin $\left(0.5 \mathrm{mg} \mathrm{L}^{-1}\right)$ and sucrose (5\%) and cultured as described by Ali et al. [13]. These proliferated roots were used as explants and named as Chungbuk National University Line $1(\mathrm{CBN}-1)$ for further experiments.

\section{Treatment with elicitors}

Forty five day-old adventitious roots (1-2 cm, $22 \mathrm{~g}$ FW/L inoculums) were treated with MJ or SA $(200 \mu \mathrm{M})$ in a $5 \mathrm{~L}$ airlift balloon type bioreactor containing $4 \mathrm{~L} 75 \%$ strength $\mathrm{MS}$ liquid medium supplemented with IBA (5.0 $\left.\mathrm{mg} \mathrm{L}^{-1}\right)$, kinetin $\left(0.5 \mathrm{mg} \mathrm{L}^{-1}\right)$ and sucrose $\left(50 \mathrm{~g} \mathrm{~L}^{-1}\right)$. The MJ and SA solutions were filter-sterilized before use and were aseptically added to the culture medium. In controls, the same amount of medium was added. The air was supplied to each bioreactor at an appropriate flow rate through one of the filters at a total gas flow of $400 \mathrm{~mL} \mathrm{~min}^{-1}$ using an Eyela F140 gas control unit. The compositions of supplied air in control and in treatment was same as atmospheric air composition $\left(\mathrm{N}_{2} 78 \%, \mathrm{O}_{2} 20.3 \%\right.$, Ar $0.9 \%$ and $\mathrm{CO}_{2}$ 0.03\%). The air temperature in the bioreactor was controlled at $22 \pm 1^{\circ} \mathrm{C}$ using the air controller system. Four separate bioreactors were used for each treatment and roots were cultivated after 3, 5, 7 and 9 days. Each time separate control roots also collected from separate bioreactor. Roots were cleaned first with running tap water for 5-7 min and 
washed again with distilled water. Roots were then blotted dry and a sample (1 g) weighed in an Eppendorf tube and placed immediately in liquid nitrogen and kept in $-80{ }^{\circ} \mathrm{C}$ until analysed.

\section{Determination of root growth}

The growth of the adventitious roots was measured in terms of FW and DW. Roots were placed between the folds of blotting paper to remove excess water and weighted for the determination of FW. DW was measured after drying the fresh roots in an oven at $60 \pm 1^{\circ} \mathrm{C}$ for $48 \mathrm{~h}$.

\section{Determination of protein carbonyl and hydrogen peroxide contents}

Roots were homogenised in phosphate buffer ( $\mathrm{pH} 7.0,50 \mathrm{mM})$ containing ethylenediamine tetra acetic acid (EDTA, $1 \mathrm{mM}$ ), phenylmethylsulfonyl fluoride (PMSF, $1 \mathrm{mM}$ ) and leupeptin (10 mg dissolved in $2 \mathrm{~mL}$ water, $50 \mu \mathrm{L} \mathrm{mL}^{-1}$ ) and centrifuged at $19,000 \times \mathrm{g}$ for $20 \mathrm{~min}$. Protein carbonyl contents were analyzed using the 2,4-dinitrophenylhydrazine method as described by Levine et al. [33] and measured at $366 \mathrm{~nm}$ using the extinction coefficient $(\varepsilon)$ of $22.0 \mathrm{mM}^{-1} \mathrm{~cm}^{-1}$. Hydrogen peroxide was measured following the method of Alexieva et al. [34]. The amount of $\mathrm{H}_{2} \mathrm{O}_{2}$ was calculated using a standard curve prepared with known concentrations of $\mathrm{H}_{2} \mathrm{O}_{2}$.

Determination of total phenolics, flavonoids, ascorbic acid, cysteine and NPSH contents and DPPH activity

For total phenolics and flavonoids, roots were homogenised in 95\% ethanol (1 mL) and kept in the freezer for 48-72 h. The sample was then centrifuged at 19,000 x g for $20 \mathrm{~min}$ and measured following Shetty et al. [35] and Zhuang et al. [36], respectively. Fresh supernatant was used for flavonoids contents determination. The phenolics and flavonoids contents were measured using gallic acid and catechin as standards, respectively. For, ascorbic acid determination, roots frozen in liquid $\mathrm{N}_{2}$ were ground with freshly prepared 2\% metaphosphoric acid. They were then centrifuged at 19,000×g for 15 min [37]. The supernatant was kept in the dark on ice until use. One $\mathrm{mL}$ of supernatant was mixed with water ( $1 \mathrm{~mL}), 2 \%$ metaphosphoric acid (v/v, $1 \mathrm{~mL})$, sodium citrate buffer $(0.1 \mathrm{M}, \mathrm{pH}$ 2.3, $0.5 \mathrm{~mL})$ and dichlorophenol indophenol (DCPIP, $100 \mathrm{mgL}^{-1}, 1 \mathrm{~mL}$ ). Ascorbic acid was determined at $524 \mathrm{~nm}$ by measuring the reduction of DCPIP. The amount of ascorbate present was calculated with reference to a standard curve. DPPH reducing activity, protein, cysteine and NPSH contents were measured following Hatano et al. [38], Bradford [39], Gaitonde [40] and Ellman [41], respectively.

\section{Determination of phenylpropanoid pathway enzymes}

For G6PDH, SKDH and CAD, roots were homogenised in $0.1 \mathrm{M}$ K-phosphate buffer (pH 7.4) containing dithiothreitol (DTT, $0.5 \mathrm{mM})$, L-cysteine (2 mM), EDTA (2 mM), 2-mercaptoethanol $(8 \mathrm{mM})$ and polyvinylpolypyrolidone (PVPP, 0.5\%). G6PDH (EC 1.1.1.49) activity was measured in $50 \mathrm{mM}$ Tris- $\mathrm{HCl}$ (pH 7.4) containing $\mathrm{MgCl}_{2}(5 \mathrm{mM})$, glucose 6 phosphate $(0.5 \mathrm{mM})$ and NADP $(0.5 \mathrm{mM})$ [42]. The reaction was initiated by the addition of extract and increase in absorbance at 
$340 \mathrm{~nm}\left(\varepsilon, 6.22 \mathrm{mM}^{-1} \mathrm{~cm}^{-1}\right)$ was recorded. The SKDH (EC 1.1.1.25) assay was performed in a reaction medium containing shikimic acid $(2 \mathrm{mM})$ and NADP $(0.5 \mathrm{mM})$ in Tris-HCl buffer $(\mathrm{pH} 9.0,0.1 \mathrm{M})$ [43]. The reaction was initiated by the addition of extract and increase in absorbance at $340 \mathrm{~nm}(\varepsilon$, $6.22 \mathrm{mM}^{-1} \mathrm{~cm}^{-1}$ ) was recorded following the NADP reduction. The CAD (EC 1.1.1.195) assay was performed on a sample $(1 \mathrm{~mL})$ containing Tris- $\mathrm{HCl}(\mathrm{pH} 8.8,100 \mathrm{mM})$, coniferyl alcohol (0.5 mM), NADP $(1 \mathrm{mM})$ and enzymatic extract. The increase in absorbance was monitored at $400 \mathrm{~mm}(\varepsilon, 21$ $\mathrm{mM}^{-1} \mathrm{~cm}^{-1}$ ) following coniferyl alcohol oxidation [44].

For PAL, roots were homogenised with $\beta$-mercaptoethanol (15 mM), Tris- $\mathrm{HCl}(\mathrm{pH} \mathrm{7.8,} 20 \mathrm{mM})$ containing glycerol (20\%), PMSF (1 mM) and Triton X-100 (1\%, v/v). PAL (EC 4.3.1.5) activity was determined on a sample containing L-phenylalanine $(11 \mathrm{mM})$ in Tris- $\mathrm{HCl}(\mathrm{pH} 8.8,100 \mathrm{mM})$ and the required amount of protein [45]. The formation of trans-cinnamic acid was monitored at $290 \mathrm{~nm}$. PAL activity is defined as the amount of enzyme forming $1 \mathrm{nmol}$ of trans-cinnamic acid from the substrate phenylalanine per min at $30{ }^{\circ} \mathrm{C}$. For CGA and CA activity, roots were homogenised with $\mathrm{Na}_{2} \mathrm{HPO}_{4} / \mathrm{NaH}_{2} \mathrm{PO}_{4}(\mathrm{pH} 6.8,50 \mathrm{mM})$ and sodium metabisulphite $(1 \%$, w/v). Assays of CGP and CA were conducted as described by Mäder et al. [46]. The CGA assay consisted of potassium phosphate buffer (pH 6.5, $50 \mathrm{mM}$ ) containing chlorogenic acid (2 mM), $\mathrm{H}_{2} \mathrm{O}_{2}(3 \mathrm{mM})$ and protein. The oxidation of CGA was monitored by measuring the changes in absorbance at $410 \mathrm{~nm}\left(\varepsilon, 2.02 \times 10^{5} \mathrm{M}^{-1} \mathrm{~cm}^{-1}\right)$.

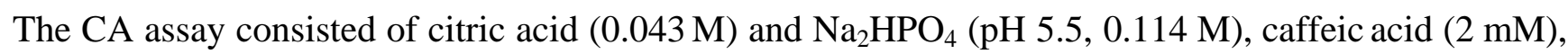
$\mathrm{H}_{2} \mathrm{O}_{2}$ (3 mM) and protein. The oxidation of CA was monitored by determining the changes in absorbance at $410 \mathrm{~nm}\left(\varepsilon, 1.5 \times 10^{5} \mathrm{M}^{-1} \mathrm{~cm}^{-1}\right)$. For QP and FA activity, roots were homogenized with Tris-HCl (pH 7.5, $0.25 \mathrm{M}$ ) containing EDTA (3 mM), DTT (20 mM), PMSF (0.1 mM) and PVPP (2\%). The oxidation of quercetin and ferulic acid were monitored by the changes in absorbance at 380 $\mathrm{nm}\left(\varepsilon, 13.6 \mathrm{mM}^{-1} \mathrm{~cm}^{-1}\right)$ and at $318 \mathrm{~nm}\left(\varepsilon, 15.2 \mathrm{mM}^{-1} \mathrm{~cm}^{-1}\right)$, respectively. The reactions were carried out in a sample $(1 \mathrm{~mL})$ of citrate buffer $(\mathrm{pH} 4.5,0.1 \mathrm{M}), \mathrm{H}_{2} \mathrm{O}_{2}(0.6 \mathrm{mM})$, quercetin $(1 \mathrm{mM})$ and ferulic acid (1 mM) [47].

\section{Determination of proline and $\beta$-GS activity}

Proline was estimated at $515 \mathrm{~nm}$ of the ninhydrin reaction according to Bates et al. [48]. $\beta$-GS (EC 3.2.1.21) activity was assayed in sodium acetate ( $\mathrm{pH} 4,25 \mathrm{mM})$, containing 2- $\beta$-mercaptoethanol (40 $\mathrm{mM})$ and $p$-nitrophenyl $\beta$-D-glucopyranoside ( $2 \mathrm{mM})$ [49]. The reaction was initiated by the addition of extract $(0.5 \mathrm{~mL})$ to the substrate $(2 \mathrm{~mL})$ at $70{ }^{\circ} \mathrm{C}$ for $2 \mathrm{~min}$. The reaction terminates after $2 \mathrm{~min}$ by the addition of $1 \mathrm{M} \mathrm{Na}_{2} \mathrm{CO}_{3}$ solution $(1 \mathrm{~mL}$ ). The $\beta$-GS activity was defined as the amount of enzyme that produced $1 \mu \mathrm{mol}$ of $p$-nitrophenol per min at $400 \mathrm{~nm}\left(\varepsilon, 18.3 \mathrm{mM}^{-1} \mathrm{~cm}^{-1}\right)$. For enzymatic analysis, each supernatant was passed through the PVDF syringe filter (Whatman, $13 \mathrm{~mm}, 0.45 \mu \mathrm{m}$ ) and assayed as described above. All procedures were carried out at $0-4{ }^{\circ} \mathrm{C}$.

\section{Statistics}

All experiments were carried out in triplicate. Significant differences are marked by different letters following Duncan's Multiple Range Tests (DMRT) using SAS program (Version 6.12, SAS Institute Inc., Cary, USA) at $P<0.05$ and 0.01. Bars represent standard error (SE). 


\section{Acknowledgements}

This work was financially supported by the Ministry of Education and Human Resources Development (MOE), the Ministry of Commerce, Industry and Energy (MOCIE) and the Ministry of Labor (MOLAB), Republic of Korea, through the Lab of Excellency Fostering Project. One of the authors (M.B.A) also wishes to acknowledge the Japanese Society for the Promotion of Science (JSPS) for providing financial assistance.

\section{References}

1. Solecka, D.; Kacperska, A. Phenylpropanoid deficiency affects the course of plant acclimation to cold. Physiol. Plant. 2003, 119, 253-262.

2. Ali, M.B., Khatun S.; Hahn, E.J.; Paek, K.Y. Enhancement of phenylpropanoid enzymes and lignin in Phalaenopsis orchid and their influence on plant acclimatisation at different levels of photosynthetic photon flux. Plant Grow Regul. 2006, 49, 137-146.

3. Dixon, R.A.; Paiva, N.L. Stress-induced phenylpropanoid metabolism. Plant Cell 1995, 7, 10851097.

4. Weaver, L.M.; Herrmann, K.M. Dynamics of the shikimate pathway in plants. Trends Plant Sci. 1997, 2, 346-351.

5. Randhir, R.; Vattem, D.A.; Shetty, K. Antioxidant enzyme response studies in $\mathrm{H}_{2} \mathrm{O}_{2}$-streesed procine muscle tissue following treatment with faba bean sprout extract and L-DOPA. J. Food Biochem. 2006, 30, 671-698.

6. Ratledge, C. Nutrition, growth and metabolism. In The Biology of the Mycobacteria; Ratledge, C.; Stanford, J.L., (Eds.); Academic Press: London, 1982; vol. 1, pp. 185-27.

7. Blanco, P.R.; Medina, E.N.; Lopez, R.J.A.; Gonzalez, R.J.A.; Villalba, J.M.; Moyano, E.; Caballero, J.L.; Munoz, B.J. Cloning, expression and immunolocalization pattern of a cinnamyl alcohol dehydrogenase from strawberry. J. Exp. Bot. 2002, 53, 723-1734.

8. Cvikrová, M.; Malá, J.; Hrubcová, M.; Eder, J. Soluble and cell wall-bound phenolics and lignin in Ascocalyx abietina infected Norway spruces. Plant Sci. 2006, 170, 563-570.

9. Schlag, E.M.; McIntosh, M.S. Ginsenoside content and variation among and within American ginseng (Panax quinquefolius L.) populations. Phytochemistry 2006, 67, 1510-1519.

10. Gillis, C.N. Panax ginseng pharmacology: A nitric oxide link? Biochemical Pharmacol. 1997, 54, 1-8.

11. Ding, C.K.; Wang, C.Y.; Gross, K.C.; Smith, D.L. Jasmonate and salicylate induce the expression of pathogenesis-related-proteins genes and increase resistance to chilling injury in tomato fruit. Planta 2002, 214, 895-901.

12. Lee, A.; Cho, K.; Jang, S.; Rakwal, R.; Iwahashi, H.; Agrawal, G.K.; Shim, J.; Han, O. Inverse correlation between jasmonic acid and salicylic acid during early wound response in rice. Biochem. Biophys. Res. Commun. 2004, 318, 734-738.

13. Ali, M.B.; Yu, K.W.; Hahn, E.J.; Paek, K.Y. Methyl jasmonate and salicylic acid elicitation induces ginsenosides accumulation, enzymatic and non-enzymatic antioxidant in suspension culture Panax ginseng roots in bioreactors. Plant Cell Rep. 2006, 25, 613-620. 
14. Bravo, L. Polyphenols: Chemistry, dietary sources, metabolism and nutritional significance. Nut. Rev. 1998, 56, 317-333.

15. Conrath, U.; Pieterse, C.M.J.; Mauch-Mani, B. Priming in plant-pathogen interactions. Trends Plant Sci. 2002, 7, 210-216.

16. Tan, J.; Schneider, B.; Svatos, A.; Bednarek, P.; Liu, J.; Hahlbrock, K. Universally occurring phenylpropanoid and species-specific indolic metabolites in infected and uninfected Arabidopsis thaliana roots and leaves. Phytochemistry 2004, 65, 691-699.

17. Santos, M.R.; Mira, L. Protection by flavonoids against the peroxynitrite-mediated oxidation of dihydrorhodamine. Free Radic. Res. 2004, 38, 1011-1018.

18. Kim, H.J.; Chen, F.; Wang, Xi; Choi, J.H. Effect of methyl jasmonate on phenolics, isothiocyanate, and metabolic enzymes in radish sprout (Raphanus sativus L.). J. Agric. Food Chem. 2006, 54, 7263-7269.

19. Foyer, C.H.; Noctor, G. Redox homeostasis and antioxidant signaling: a metabolic interface between stress perception and physiological responses. Plant Cell 2005, 17 1866-1875.

20. Smith, I.K.; Vierheller, J.L.; Thorne, C.A. Properties and function of glutathione reductase in plants. Physiol. Plant.1989, 77, 449-456.

21. Hare, P.D.; Cress, W.A. Metabolic implications of stress-induced proline accumulation in plants. Plant Growth Regul. 1997, 21, 79-102.

22. Jyothsnakumari, G.; Sudhakar, C. Effects of jasmonic acid on groundnut during early seedling growth. Biol. Plant. 2003/2004, 47, 453-456.

23. Misra, N.; Gupta, A.K. Effect of salt stress on proline metabolism in two high yielding genotypes of green gram. Plant Sci. 2005, 169, 331-339.

24. Esen, A. $\beta$-glucosidases: overview; In $\beta$-glucosidases: biochemistry and molecular biology; Esen A.; Ed.; American Chemical Society: Washington DC, 1993; pp. 1-14.

25. Mazzuca, S.; Uccella N. $\beta$-glucosidase releasing of phytoalexin derivatives from secobiophenols as defence mechanism against pathogenic elicitors in olive drupes. Acta Hort. 2002, 586, 529-531.

26. Reymond, P.; Farmer, E.E. Jasmonate and salicylate as global signals for defense gene expression. Curr. Opin. Plant Biol. 1998, 1, 404-411.

27. Thulke, O.; Conrath, U. Salicylic acid has a dual role in the activation of defence-related genes in parsley. Plant J. 1998, 14, 35-42.

28. Brader, J.L.G.; Palva, E.T. The WRKY70 transcription factor: a node of convergence for jasmonate-mediated and salicylate mediated signals in plant defense. Plant Cell 2004, 16, 319331.

29. Rao, M.V.; Lee, H.I.; Creelman, R.A.; Mullet, J.E.; Davis, K.R. Jasmonic acid signaling modulates ozone-induced hypersensitive cell death. Plant Cell 2000, 12, 1633-1646.

30. Farrell, R. L.; Murtagh, K. E.; Tien, M.; Mozuc, M. D.; Kirk, T. K. Physical and enzymatic properties of lignin-peroxidase isoenzymes from Phanerochaete chrysosporium. Enz. Microb. Technol. 1989, 11, 322-328

31. Kobayashi, A.; Koguchi, Y.; Kanzaki, H.; Kajiyama, S.; Kawazu, K. A new type of antimicrobial phenolics produced by plant peroxidase and its possible role in the chemical defense system against plant pathogens. Z. Naturforsch. 1994, 49, 411-414. 
32. Murashige, T.; Skoog, F. A revised medium for rapid growth and bioassays with tobacco tissue. Physiol. Plant. 1962, 15, 473-497.

33. Levine, R.; Tenhaken, R.; Dixon, R.A.; Lamb, C. $\mathrm{H}_{2} \mathrm{O}_{2}$ from the oxidative burst orchestrates the plant hypersensitive disease resistance response. Cell 1994, 79, 583-593.

34. Alexieva, V.; Sergiev, I.; Mapelli, S.; Karanov, E. The effect of drought and ultraviolet radiation on growth and stress markers in pea and wheat. Plant Cell Environ. 2001, 24, 1337-1344.

35. Shetty, K.K.; Curtis, O.F.; Levin, RE.; Withowsky, R.; Ang, W. Prevention of vitrification associated with in vitro shoot cultures of oregano (Origanum vulgare) by Pseudomona spp. J. Plant Physiol. 1995, 147, 447-451.

36. Zhuang, X.; Lu, P.Y.Y.; Yang, G.S. Extraction and determination of flavonoid in ginkgo. Chin. Herb. Med. 1992, 23, 122-124.

37. Franke, W. Ascorbinsaure. In Moderne Methoden der Pflanzenanalyse; Paech, K.; Tracey M.V., (Eds.); Springer: Berlin, 1955; Vol. 2, pp. 95-112.

38. Hatano, T.; Kagawa, H.; Yasuhara, T.; Okuda, T. Two new flavonoids and other constituents in licorice: their relative astringency and radical scavenging effects. Chem. Pharm. Bull. 1988, 36, 2090-2097.

39. Bradford, M.M. A rapid and sensitive method for the quantitation of microgram quantities of protein utilizing the principle of protein-dye binding. Anal. Biochem. 1976, 72, 248-254.

40. Gaitonde, M.K. A spectrophotometric method for the direct determination of cysteine in the presence of other naturally occurring amino acids. Biochem. J. 1967, 104, 627-633.

41. Ellman, G.L. Tissue sulfhydril groups. Arch. Biochem. Biophys. 1959, 82, 70-71

42. Debnam, P.M.; Emes, M.J. Subcellular distribution of enzymes of the oxidative pentose phosphate pathway in root and leaf tissues. J. Exp. Bot. 1999, 50, 1653-61.

43. Díaz, J.; Ros, Barceló, A.; Merino, F. Changes in shikimate dehydrogenase and the end products of the shikimate pathway, chlorogenic acid and lignins, during the early development of seedlings of Capsicum annuum. New Phytol. 1997, 136, 183-88.

44. Mitchell, H.J.; Hall, J.L.; Barber, M.S. Elicitor induced cinnamyl alcohol dehydrogenase activity in lignifying wheat (Triticum aestivum L.) leaves. Plant Physiol. 1994, 104, 551-56.

45. Raag, H.; Kuhn, D.N.; Kahlbroeck, K. Coordinated regulation of coumarate: CoA ligase and phenylalanine ammonia lyase mRNA in cultured plant cells. J. Biol. Chem. 1984, 256, 52-60.

46. Mäder, M.; Nessel, A.; Boff, M. On the physiological significance of the isozyme groups of peroxidase from tobacco demonstrated by biochemical properties. Z. Pflanzenphysiol. 1977, 82, 247-60.

47. Francisco, J.P.; Daniel, V.; Nilo, M. Ascorbic acid and flavonoid-peroxidase reaction as a detoxifying system of $\mathrm{H}_{2} \mathrm{O}_{2}$ in grapevine leaves. Phytochemistry 2002, 60, 573-580.

48. Bates, L.S.; Waldren, R.P.; Teare, I.K. Rapid determination of free proline for water stress studies. Plant Soil 1973, 39, 205-208.

49. Legin, E.; Copinet, A.; Duchiron, F. Production of thermostable amylolytic enzymes by Thermococcus hydrothermalis. Biotechnol Letts. 1998, 20, 363-367.

Sample Availability: Contact the authors.

(c) 2007 by MDPI (http://www.mdpi.org). Reproduction is permitted for noncommercial purposes. 